\title{
Studi Pengalihan Mata Pencaharian Sektor Perikanan (Nelayan) Ke Usaha Non Perikanan Di Kelurahan Tomalou Kecamatan Tidore Selatan Kota Tidore Kepulauan
}

\author{
Suhardi \\ Dosen pada Program Studi Agribisnis, Fakultas Pertanian dan Kehutanan Universitas Nuku \\ (Tulisan ini merupakan saduran Skripsi penulis yang akan di kembangkan menjadi Proposal \\ Penelitian Dosen Pemula)
}

\begin{abstract}
ABSTRAK
Tujuan penelitian ini adalah untuk mengetahui seberapa besar profitabilitas mata pencaharian sebagai nelayan, menjelaskan seberapa besarkah biaya yang di butuhkan dalam usaha perikanan ( nelayan viber ), dan mengatahui seberapa besar persentase kecenderungan nelayan beralih profesi ke mata pencaharian lain, yang di laksanakan di Kelurahan Tomalou Kecamatan Tidore Selatan Kota Tidore Kepulauan pada bulan Mei sampai dengan Juni 2010. Variabel yang di amati pada penelitian ini meliputi wawancara langsung kepada para nelayan dengan menggunakan kusioner. Penilaian pada pengamatan penelitian ini meliputi : Pendapatan nelayan, biaya yang di butuhkan dan peralihan mata pencaharian.

Metode pengumpulan data di lakukan dengan wawancara langsung kepada responden menggunakan koisioner yang selanjutnya di analisis menggunakan analisis ekonomi antara lain dengan menggunakan analisis R/C Ratio, Net Persent Value, Internal Rate of Return, dan Pay back Period. Kemudian juga di analisis menggunakan analisis statistic.

Dari hasil penelitian dapat di jelaskan bahwa hanya 3 nelayan yang memiliki usaha yang layak untuk di kembangkan sebab prospek dan kebutuhan akan konsumsi ikan oleh masyarakat sangat tinggi.

Dan dapat di ketahui bahwa persentase peralihan profesi dari nelayan ke wiraswasta sebanyak $69 \%$ dan $8 \%$ sebagai petani.
\end{abstract}

Kata Kunci : Study Peraliahan, Mata pencaharian, Usaha Non Perumahan 


\section{PENDAHULUAN}

\subsection{Latar Belakang}

Sebagaimana kita ketahui bahwa Indonesia termasuk lima Negara terbesar di dunia, dalam jumlah penduduk. Asset ini dapat di jadikan sebagai salah satu kekuatan Bangsa Indonesia dalam menghadapi persaingan global, jika dikembangkan secara efektif.

Pengembangan sumberdaya Manusia Indonesia untuk menjadi pegawai atau karyawan tampaknya menghadapi keterbatasan kesempatan walau bagi yang benar-benar ahli atau terampil, tetap masih ada peluang.

Wilayah pesisir dan laut Indonesia merupakan suatu kawasan yang sangat strategis ditinjau dari segi teknis, keamanan, sosial maupun ekonomi. Hal tersebut dapat dipahami karena selain wilayah pesisir Indonesia memiliki garis pantai sepanjang $81.000 \mathrm{~km}$ atau terpanjang kedua di dunia serta memiliki keanekaragaman hayati tertinggi di dunia, juga sekitar 140 juta penduduk Indonesia mendiami wilayah pesisir. Dalam dua dekade ini, laju pemanfaatan sumberdaya pesisir bagi pembangunan semakin pesat. Hal ini terlihat dari aktivitas ekonomi yang memanfaatkan sumberdaya pesisir dan jasa lingkungannya telah menyumbang sekitar 24,5\% dari Gross Domestic Product. Fakta menunjukkan bahwa bagian terbesar masyarakat pesisir masih menjadi marginal akibat pola pengelolaan sumberdaya wilayah pesisir dan laut yang belum berkelanjutan serta kurang memperhatikan kaidah- 
kaidah konservasi. Di beberapa kawasan pesisir dan laut yang padat penduduk dan tinggi intensitas pembangunannya, terjadi laju kerusakan biogeofisik lingkungan habitat utama pesisir seperti kerusakan mangrove, terumbu karang, padang lamun, estuari, termasuk intensitas pencemaran dari darat, tangkap ikan lebih (over fishing) dan abrasi pantai telah mencapai tingkat mengkuatirkan. ( Anonim, 2007 )

Hal di atas jika dibandingkan dengan Jumlah Rakyat Indonesia yang kurang lebih 81,2 \% dari total seluruh Rakyat Indonesia tinggal di pedesaan-pedesaan sebagai petani dan keluarga petani yang rata-rata dapat dikatakan sangat lemah perekonomiannya. Keadaan demikian di karenakan cara-cara bertani mereka yang tradisional selain itu (a) Prasarana dan sarana yang mendukungnya kurang memadai (b) Cara-cara bertani yang sesuai dengan kemajuan jaman kurang di ketahui, (c) Pasar yang dapat menampung produk-produk pertanian sangat langka dan kalaupun ada pada waktu itu produk-produk pertanian hanya dapat di perdagangkannya dengan harga yang kurang wajar yang jelas tidak menguntungkannya. ( Kartasapotra, 1992 )

Keadaan demikian jelas tidak menimbulkan gairah pada para petani untuk meningkatkan produksi pertaniannya, sehingga pendapatan mereka tetap kecil dan inilah yang menjadikan mereka hidup dalam perekonomiannya yang sangat lemah.

Berbagai upaya yang telah di lakukan oleh Pemerintah Indonesia maupun NGO baik NGO dalam negeri maupun NGO luar negeri dalam upaya peningkatan kapasitas sumber daya manusia dengan memanfatkan potensi yang ada.

Pembangunan Lima Tahun I,II,III, di bidang Pertanian yang telah di laksanakan oleh pemerintah dengan partisipasi dari seluruh masyarakat petani di tanah air kita, hasilnya benar-benar telah dapat di rasakan oleh seluruh bangsa kita. Bukan saja seluruh kebutuhan akan pangan seluruh Rakyat Indonesia hampir dapat di katakan telah tercukupi dengan 
Swasembada, melainkan juga export hasil-hasil pertanian dari Negara kita ke luar negeri menjadi meningkat.

Keadaan demikian kalau kita hubungkan dengan pola umum PELITA III mengenai bidang pertanian, dapat di katakana bahwa pola umum tersebut dapat di penuhi dengan sebaik-baiknya. Untuk jelasnya dapat di kemukakan tentang pola umum tersebut sebagai berikut bahwa

a) Pembangunan pertanian di lanjutkan dalam rangka meningkatkan produksi pangan, meningkatkan eksport, meningkatkan penghasilan petani dan memungkinkan dukungan yang kuat terhadap pembangunan idustri.

b) Peningkatan produksi perkebunan, kehutanan dan perikanan, di samping untuk meningkatkan perluasan lapangan kerja dan penghasilan rakyat, juga bertujuan untuk menunjang pembangunan Industri serta meningkatkan Eksport.

Dalam era Industrialisasi yang akan di capai dalam pembangunan jangka panjang, Pembanguan Industri nasional mendapatkan perhatian yang serius agar mampu menciptakan suatu masyarakat Industri yang maju dan lebih Transformatif yaitu masyarakat yang maju baik secara struktural maupun secara Kultural.

Dimensi Struktural tercermin pada upaya merubah masyarakat yang tadinya agraris yang tradisional menjadi masyarakat industry yang di topang pada dua kekutan pokok yaitu Industri yang kuat di dukung oleh pertanian yang tangguh mencakup penguasaan teknologi serta mempunyai daya saing yang kuat dalam memasuki era pasar global. Sedangkan dalam dimensi Kultural tercermin dalam nilai-nilai baru yang berkembang sangat bermanfaat dalam menopang terbentuknya suatu masyarakat industri yaitu menyangkut sikap dan tingkahlaku rasional masyarakat, etos kerja, menghargai waktu, kompetisi, orientasi ke masa depan yang lebih mandiri serta produktif. 
Berangkat dari pejelasan di atas, proses Industrialisasi dan pembangunan industri pada hakekatnya merupakan salah satu upaya untuk meningkatkan kesejahteraan Rakyat, dalam arti peningkatan taraf hidup yang lebih maju.

Seiring dengan peningkatan pembangunan industry, nilai produksi industri juga mengalami peningkatan yang signifikan. Peningkatan nilai produksi ini juga di dorong oleh semakin tingginya daya beli konsumen terhadap produk-produk yang di hasilkan.

Kota Tidore Kepulauan merupakan salah satu daerah otonom dalam Wilayah Propinsi Maluku Utara yang terbentuk berdasarkan Undang-Undang Nomor 1 Tahun 2003, dimana sebelumnya adalah termasuk wilayah Kabupaten Halmahera Tengah. Terbentuknya Kota Tidore Kepulauan memiliki latar belakang yang panjang, tetapi yang paling utama adalah :

1. Sebagai bekas Pusat Kekuasaan Kesultanan Tidore pada masa lalu hingga kini.

2. Terdapat kota Sofifi sebagai pusat pemerintahan Propinsi Maluku Utara, maka pembangunan Kota Tidore Kepulauan pada hakektanya adalah pembangunan "wajah" Propinsi Maluku Utara.

Menurut publikasi Kementerian Percepatan Pembangunan Daerah Tertinggal tahun 2004 Kota Tidore Kepulauan tidak termasuk dalam kategori daerah tertinggal, namun kalau melihat dari dekat kondisi obyektif yang ada, sebenarnya daerah ini masih tergolong daerah yang belum berkembang alias tertinggal. Kondisi ketertinggalan dan keterisolasian ini sebagai akibat dari minimnya sarana dan prasarana social dan ekonomi. Hal ini tidak berbanding lurus dengan potensi kekayaan sumberdaya alamnya, yang jika di kelola secara optimal dapat meningkatkan kesejahteraan masyarakat di daerah ini.

Masalahnya adalah arah dan kebijakan pembangunan selama ini tidak berdasarkan pertimbangan karakteristik wilayah. Penyeragaman kebijakan pembangunan nasional di masa lalu telah berimplikasi serius terhadap perkembangan pembangunan di daerah-daerah yang jauh dari pusat pemerintahan Negara, termasuk daerah Kota Tidore Kepulauan. Keberpihakan 
pembangunan pada masa lalu hanya berada di pusat-pusat kegiatan social ekonomi tertentu, sementara daerah-daerah penyanggah (binterland) kurang mendapat perhatian. Implikasi kebijakan pembangunan nasional di masa lalu tersebut harus segera di reorientasi dengan pendekatan pembangunan berorientasi kewilayahan. Yaitu pemetaan terhadap wilayahwilayah potensial yang harus di kembangkan berdasarkan potensi wilayahnya yang di dukung oleh ketersediaan sarana dan prasarana social ekonominya.

\subsection{Perumusan Masalah}

Berdasarkan uraian Latar Belakang di atas maka penulis merumuskan masaalah adalah seberapa besarkah profit mata pencaharian sebagai nelayan dan mata pencaharian non perikanann di Kelurahan Tomalou Kecamatan Tidore Selatan Kota Tidore Kepulauan.

\subsection{Tujuan dan Kegunaan Penelitian}

Sesuai dengan permasalahan di atas maka tujuan penelitian ini adalah :

1.3.1. Menjelaskan seberapa besar profitabilitas mata pencaharian sebagai nelayan perikanan di Kelurahan Tomalou Kota Tidore Kepulauan.

1.3.2. Dapat menjelaskan seberapa besarkah biaya yang di butuhkan dalam usaha perikanan perikanan di Kelurahan Tomalou Kota Tidore Kepulauan.

1.3.3. Untuk mengetahui seberapa besar persentase kecenderungan peralihan profesi sebagai nelayan ke profesi lainnya di Kelurahan Tomalou Kota Tidore Kepulauan.

Kemudian penelitian ini dapat diharapkan bermanfaat bagi pengusaha yang pada umumnya memiliki persamaan masaalah menyangkut upaya meningkatkan keberhasilan usaha dan pengembangannya. 


\section{TINJAUAN PUSTAKA}

\subsection{Modal}

Sebelum memulai suatu kegiatan bisnis, modal kerja sangat memiliki peranan penting, terutama untuk kelanjutan bisnis jangka panjang. Modal kerja yang tak terkontrol dengan baik akan mengakibatkan ketidak terkendalinya pemanfaatan modal kerja, sehingga apa yang di harapkan semula tidak sesuai dengan apa yang di dapat. ( Sadikin FX 2005 : 49)

Manulang ( 1996 :16) mengemukakan bahwa untuk melakukan berbagai aktifitas di perlukan uang, seperti upah atau gaji orang-orang yang kegagalan atau ketidak lancaran proses suatu kegiatan usaha sedikit banyak ditentukan atau dipengaruhi oleh perhitungan atau ketelitian dalam menggunakan uang.

Modal adalah barang atau uang yang bersama-sama dengan faktor-faktor produksi tanah dan tenaga kerja menghasilkan barang-barang baru yaitu dalam hal ini hasil pertanian. (Mubyarto, 1989)

Dalam proses produksi modal usaha digolongkan atas dua yaitu modal tetap adalah modal yang di pakai berkali-kali dalam proses produksi, sedangkan modal tidak tetap adalah modal yang habis di pakai dalam satu kali proses produksi. (Hermanto, 1989)

\subsection{Manusia atau Tenaga Kerja}


Salah satu faktor produksi yang terpenting adalah manusia atau tenaga kerja, karena tanpa tenaga kerja maka proses produksi tidak dapat dilakukan meskipun proses produksi menggunakan alat dan mesin modern.

Tenaga kerja atau manusia dalam sebuah perusahaan atau dalam suatu usaha adalah sangat penting, karena tanpa tenaga kerja yang produktif upaya-upaya selanjutnya ke arah yang menguntungkan akan sia-sia belaka. Soedjadi et al. (1995) menyatakan untuk mencapai keseluruhan tujuan yang sudah ditetapkan dengan setepat-tepatnya maka salah satu sumber yang diperlukan ialah tersedianya tenaga kerja yang sesui, baik jumlah maupun mutunya.

\subsection{Konsep Biaya}

Menurut Matz - Usry dalam Akuntansi Biaya Jilid 1 bahwa biaya sebagai sutu nilai tukar, prasyarat, atau pengorbanan yang dilakukan guna memperoleh manfaat. Dalam akuntansi keuangan, prasyarat atau pengorbanan tersebut pada tanggal perolehan dinyatakan dengan pengurangan kas atau aktiva lainnya pada saat ini atau di masa mendatang.

Istilah "biaya" ( cost ) acapkali digunakan dalam arti yang sama dengan istilah "beban" ( expense ). Namun, beban dapat di defenisikan sebagai arus keluar barang dan jasa, yang akan di bebankan pada/ditandingkan ( matched ) dengan pendapatan ( revenue ) untuk menentukan laba (income).

Biaya merupakan beban yang menurut F. Rahardi (2003) di bagi dalam dua jenis yakni, Beban Langsung adalah uang atau asset yang bias di nilai dengan uang yang secara langsung dimasukkan sebagai biaya produksi (harga pokok). Sedangkan beban tidak langsung adalah uang atau aset yang bias di nilai dengan uang yang digunakan untuk membiayai kegiatan agrobisnis.

\subsection{Pasar dan Pemasaran}

Menurut Suydi Prawirosentono, bahwa Pasar merupakan pertemuan antara penjual dan pembeli untuk melakukan transaksi jual beli dalam rangka pemindahan hak atas barang 
atau jasa yang dijadikan objek jual beli. Namun, pengertian pasar di sini bukanlah makna pasar secara sempit sebab pasar yang di maksud lebih luas maknanya tempat konsumen potensial berada. Secara harfiah pemasaran berkaitan dengan usaha atau kegiatan memasarkan suatu barang atau jasa yang dilakukan produsen terhadap konsumen. Dalam hal ini memasarkan berarti menjual barang atau jasa yang ditawarkan produsen kepada konsumen. Dalam menjual suatu barang dan jasa berkaitan dengan harga barang atau jasa tersebut. Barang atau jasa yang di tawarkan minimal memiliki standarisasi harga sebelum barang dan jasa tersebut di jual kepada konsumen.

Dahl \& Hamond (1977) memberikan defenisi pasar sebagai berikut : "Market Is some, sphere, or space, (1) where the forces of demand and supply are at work, (2) to determine, or modify, price, (3) as the ownership of some quantity of good or serfice, is transferred, and (4) certain physical and institutional arrangements maybe evidence." Terjemahan bebasnya, pasar adalah sebagai sesuatu lingkungan atau ruang tempat kekuatan permintaan dan penawaran bekerja untuk menentukan atau memodofikasi harga sehingga menjadi pertukaran kepemilikan barang dan jasa serta adnya fakta kegiatan fisik dan instiitusional.

Pasar menurut Kotler (2000) yang di terjemahkan Hendra Teguh, terdiri dari semua pelanggan potensial yang mempunyai kebutuhan atau keinginan tertentu yang mungkin tersedia dan mampu melibatkan diri dalam suatu pertukaran guna memuaskan kebutuhan atau keinginan tersebut.

Winardi (1989) membagi pasar dalam pasar kongkret dan abstrak. Pasar kongkret adalah tempat peminta dan penawar berkumpul.Pasar abstrak oleh Winardi di bagi dalam tiga tafsiran, yaitu :

- Pasar abstarak adalah keseluruhan permintaan dan penawaran berhubungan satu dengan yang lain. 
- Pasar abstrak adalah keseluruhan daerah, dimana para pembeli dan penjual berhubungan dan terjadi penjualan.

- Pasar abstrak adalah keseluruhan daerah, dimana para peminta dan penawar mwmpunyai kontak sedemikian rupa, hingga barang-barang yang sama mempunyai pengaruh kuat langsung satui sama lain.

Berbagai aktifitas pemasaran produk harus diawali dengan penentuan harga jual, promosi produk, cara pendistribusian dan di dahului dengan kegiatan perencanaan. Tentu saja barang atau jasa yang akan di pasarkan adalah barang atau jasa yang mempunyai nilai dan daya guna bagi konsumen. Selain itu pelaksanaan kehiatan-kegiatan tersebut harus dikendalikan secara terpadu.

Defenisi marketing menurut Philip Kotler adalah " Marketing is the analysis, planning, implementations and control of carefully formulated programs designed to bring about voluntary exchanges of values with target markets to achieve institutional objectives."

Pemasaran adalah analisis, perencanaan, dan pengendalian dari suatu program yang telah diformulasikan dan dirancang secara seksama untuk menciptakan pertukaran nilai secara sukarela dalam suatu pasar yang ditargetkan, untuk mencapai tujuan perusahaan.

Dalam setiap usaha tentunya mempunyai tujuan untuk dapat terus dipertahankan dan dikembangkan untuk mempertahankan eksistensi keberlangsungannya. Tujuan ini dapat di raih dengan upaya mempertahankan dan bahkan meningkatkan keuntungan usaha. Keuntungan hanya dapat di raih apabila setiap usaha dapat mempertahankandan meningkatkan volume penjualan barang atau jasa yang di jualnya. Tujuan ini dapat di capai melalui penentuan strategi yang tepat dengan cara memanfaatkan berbagai peluang yang terjadi dalam wilayah pemasaran, agar posisi usaha di wilayah pemasaran dapat di pertahankan atau bahkan posisinya dapat di perbaiki. Bahkan menjadi Market Leader. 
Strategi pemasaran suatu perusahaan atau setiap usaha harus mempunyai gambaran yang jelas, rinci dan terarah mengenai target dan metode pencapaian target tersebut.

Secara singkat strategi pemasaran merupakan rencana yang menyeluruh dan terpadu tentang pemasaran. Strategi tersebut secara rinci dan jelas memuat panduan tentang rangkaian kegiatan ( set of activities ) yang harus dikerjakan dan dikendalikan untuk mencapai tujuan pemasaran.

Arti strategi secara umum adalah serangkaian kebijakan pemasaran yang terpadu dan terarah yang jadi pedoman - kegiatan berbagai jenjang unit pemasaran untuk mencapai target penjualan dalam wilayah pemasaran tertentu, sesuai dengan perubahan kondisi dan lingkungan usaha bisnis bersangkutan.

Strategi pemasaran suatu usaha harus di dasarkan atas suatu analisis lingkungan internal maupun eksternal usaha. Analisis internal perusahaan adalah analisis keunggulan dan kelemahan usaha. Sedangkan analisis eksternal adalah analisis atas berbagai factor luar yang memengaruhi usaha. Analisis ini sering di kenal dengan analisis SWOT.

Dalam Suyadi Prawirosentono, mengemukakan bahwa kebijakan strategi pemasaran harus meliputi berbagai upaya menjajakii kemungkinan secara lebih rinci. Hal ini di kenal dengan istilah strategi pemasaran intensif, yang meliputi kegiatan-kegiatan berikut ini.

1. Penembusan Pasar ( market penetration )

Perusahaan berusaha melakukan penjualan produk yang di hasilkan sekarang dalam wilayah pasar yang di hadapi saat ini, dengan cara perembesan atau penembusan.

2. Pengembangan Pasar ( market development )

Setelah berhasil menembus pasar, perusahaan harus berusaha meningkatkan penjualan produknya, dengan memperluas daerahpemasaran yang baru untuk produk yang di hasilkan saat itu. Misalnya di cari daerah pemasaran baru di luar wilayah pemasaran yang di kuasai. 
3. Pengembangan Produk ( product development )

Perusahaan berusaha meningkatkan penjualan dengan cara membuat produk tipe baru, di tujukan untuk pasar-pasar yang ada. Misalnya, desain atau mutu atau kegunaannya di sempurnakan.

4. Perusahaan berusaha meningkatkan penjualan dengan membuat beragam produk dalam berbagai tipe, model, dan ukuran ( product diversivication ). Maksudnya untuk meraih kepuasan, selera, pendapatan, dan sebagainya.

Hal di atas menjadi sebuahh sinergisitas dalam menjalankan usaha dan upaya mempertahankan dan meningkatkan kelangsungan sebuah usaha. Tidak terlepas dari kesemuanya dalam system pemasaran dari suatu barang dan jasa selalu terjadi interaksi dan saling kketergantungan satu sama lain antara factor-faktor berikut :

a. Lembaga-lembaga pemasaran

b. Barang atau jasa yang di perjualbelikan

c. Pasar sebagai sarana transaksi

d. Perantara yang berfungsi menghubungkan berbagai factor tersebut

e. Lingkungan yang meliputi teknologi, social budaya, kebijaksanaan pemmerintah di bidang ekonomi dan social politik.

Messkipun setiap perusahaan mempunyai system pemasaran tersendiri yang di gunakan sebagai sarana penghubung antara perusahaan sebagai produsen dengan konsumen. Jadi system pemasaran digunakan sebagai sarana untuk memasarkan produk yang di hasilkan.

Menentukan sistem pemasaran yang akan di gunakan berkaitan dengan penetapan strategi pemasaran perusahaan. Perusahaan harus selektif dengan penuh perhitungan memilih dan menggunakan system dan strategi pemasaran. Sebab apabila tidak selektif memilih 
strategi dan system pemasaran yang tepat, mungkin akan berakibat buruk terhadap kelangsungan hidup perusahaan.

Dalam dunia usaha, setiap usaha yang didirikan tentu bertujuan memperoleh laba. Jadi, laba dalam suatu bisnis merupakan tujuan utama dan penting dalam usaha. Profitabilitas atau keuntungan merupakan sutu ukuran keberhasilan suatu usaha. Dengan demikian, seluruh unit usaha bertanggungjawab dalam mencapai tujuan bisnis.

Suyadi Prawirosentono, mengelompokkan factor ekstern maupun interen yang dapat mempengaruhi tingkat laba yang di peroleh setiap usaha, yakni sebagai berikut :

1. Besarnya biaya yang di keluarkan untuk memproduksi suatu barang atau jasa yang di cerminkan oleh harga pokok penjualan (HPP) atau harga pokok produksi (cost of goods sold).

2. Jumlah barang atau jasa yang di produksi dan di jual.

3. Harga jual barang bersangkutan.

Berdasarkan ke tiga hal di atas maka upaya pihak manajemen adalah dengan cara menekan biaya ke tingkat yang paling minimum. Di lain pihak, volume penjualan barang/jasa dapat di tingkatkan ke tingkat yang paling maksimum sehingga barang yang di produksi habis terjual.

Pengertian impas menurut Suyadi Prawirosentono, adalah bahwa total penghasilan (total revenue) perusahaan sama dengan total biaya yang di keluarkan. Dalam ilmu ekonomi mikro, dapat di kenal sebagai TR = TC, atau total revenue sama dengan total cost .

Dengan istilah lain, analisis titik impas (ATI) di kenal dalam berbagai buku sebagai Break Even Point Analisis (BEPA). Titik produksi, dimana hasil penjualan sma persis dengan total biaya produksi di sebut Titik Impas (TI) atau Break Even Point (BEP).

Analisis titik impas (TI) atau BEPA adalah analisis untuk menentukan hal-hal sebagai berikut 
1. Menentukan jumlah penjualan minimum yang harus di pertahankan agar perusahaan tidak mengalami kerugian. Jumlah penjualan minimum ini berarti juga jumlah produksi minimum yang harus di buat.

2. Selanjutnya, menentukan jumlah penjualan yang harus di capai untuk memperoleh laba yang telah direncanakan. Inipun berarti bahwa tingkat produksi harus di tetapkan untuk memperoleh laba tersebut.

3. Mengukur dan menjaga agar penjualan tidak lebih kecil dari titik impas (TI) atau BEP. Sehingga tingkat produksipun tidak kurang dari titik impas (BEP).

4. Menganalisis perubahan harga jual, harga pokok (harga) dan besarnya hasil penjualan atau tingkat produksi.

\subsection{Mata Pencaharian}

Seiring dengan kemajuan peradaban dan ilmu pengetahuan, kehidupan manusiapun bertambah kompleks. Begitupula dengan jenis- jenis kegiatan yang di lakukan oleh banyak orang. Salah satu bentuk kegiatan manusia yang paling mendasar dan sangat penting adalah masalah penghidupan. Ketika kita menyinggung tentang penghidupan manusia, maka pembahasannya tidak akan lengkap jika kita tidak mengupas segala hal yang berkaitan dengan mata pencaharian.

Mata pencaharian adalah segala kegiatan yang dilakukan untuk menghasilkan pendapatan guna memenuhi kebutuhan hidup manusia. Sang Budha menyatakan bahwa ada lima macam micchavanijja yang perlu dihindari oleh manusia yaitu :

1. Memperdagangkan barang-barang yang dipergunakan untuk membunuh makhlukmakhluk hidup, atau dengan kata lain dengan senjata.

2. Mmemperdagangkan manusia ( perdagangan budak)

3. Memperdagangkan binatang-binatang yang akan disembelih untuk makanan.

4. Memperdagangkan minuman - minuman yang memabukkan. 
5. Memperdagangkan racun.

\section{GAMBARAN UMUM LOKASI PENELITIAN}

\subsection{Letak Geografis}

Secara geograafis, Letak wilayah Kota Tidore Kepulauan berada pada batas astronomis 0 - $20^{\circ}$ Lintang Utara dan pada Posisi $127^{\circ}-127,45^{\circ}$ bagian Timur, Kota Tidore Kepulauan memiliki luas daratan 9.564.4 $\mathrm{km}^{0}$ dan luas Lauatan 4.293,2 $\mathrm{km}^{0}$ dengan batas wilayah sebagai berikut :

- Sebelah Utara berbatasan dengan Kecamatan Pulau Ternate, Kota Ternate dan Kecamatan Jailolo Selatan Kabupaten Halmahera Barat.

- Sebelah timur berbatasan dengan Kecamatan Wasile selatan, Kabupaten Halmahera Timur dan Kecamatan Weda Kabupaten Halmahera Tengah.

- Sebelah Selatan Berbatasan dengan Gane Barat Kabupaten Halmahera Selatan dan Kecamatan Pulau Moti Kota Ternate.

- Sebelah Barat berbatasan dengan laut Maluku.

Berdasarkan jumlah penduduk dalam tahun 2005 yaitu 85.263 dengan kepadatan penduduk 18 jiwa/km² yang terdiri dari laki-laki sebanyak 42.848 jiwa dan perempuan sebanyak 42.415 jiwa. 
Dari data di atas yang kemudian bila kita bandingkan dengan potensi perikanan di Kota Tidore Kepulauan penyebarannya hampir merata di semua kecamatan antara lain :

- $\quad$ Ikan cakalang / Tuna di perairan kecamatan Tidore dan Oba.

- Ikan kerapu di sepanjang pesisir pantai Kecamatan Tidore, Tidore Selatan, Tidore utara, oba dan kecamatan oba utara serta teripang, rumput laut, nener dan kerangkerangan. Dalam (Profil Kota Tidore Kepulauan, 2005).

Hal ini bila dimanfaatkan dengan secara baik oleh para usahawan swasta maupun Pemerintah dalam upaya mengurangi tingkat pengangguran, perluasan lapangan pekerjaan dan peningkatan taraf hidup masyarakat tersa sangat efektif.

Sejalan dengan total produksi ikan di Kota Tidore Kepulauan tahun 2000 hingga 2005 sebesar 20.545,3 ton dengan jumlah armada penangkapan kurang lebih 1.336 armada, Dalam ( Profil Wilayah Kota Tidore Kepulauan, 2005) maka penting kiranya didirikan sebuah industri atau perusahaan pengolahan ikan.

Dengan demikian Pemerintah Kota Tidore Kepulauan harus jeli melihat potensi dan kondisi yang ada, maka perusahaan yang menjadi perioritas untuk dikembangkan antara lain :

- Perusahaan yang memanfaatkan potensi daerah

- Perusahaan yang banyak menyerap tenaga kerja

- Perusahaan yang mempunyai prospek pasar lokal maupun export

- Perusahaan yang menunjang pariwisata

Berdasarkan data empiris di atas, maka sesuai dengan program pemerintah dalam upaya pengembangan industry pengolahan hasil-hasil pertanian dan intensifikasi industry pengolahan di pedesaan serta sasaran dari pemberdayaan koperasi dan UMKM di Kota Tidore Kepulauan. Sehingga diperlukan penelitian-penelitian guna memberikan informasi mengenai kemungkinan pengembangan usaha di daerah ini, seperti usaha penangkapan ikan serta akses pasar penjualan ikan paska panen ikan di Kota Tidore Kepulauan. 
Dalam data monografi Kelurahan Tomalou 2010 Secara gegrafis Kelurahan Tomalou memiliki luas wilayah 467 Ha. yang sebelah utara berbatasan dengan Pegunungan Kie matubu, sebelah selatan berbatasan dengan Pulau Mare, sebelah barat berbatasan dengan Kelurahan Tuguiha, sebelah Timur berbatasan dengan Kelurahan Gurabati.

\subsection{Keadaan Penduduk}

Jumlah penduduk yang berdomosili di Kelurahan Tomalou sebanyak 3138 jiwa dengan jumlah penduduk berdasarkan jenis kelamin laki-laki sebanyak 1515 sedangkan perempuan sebanyak 1663 orang dan yang berstatus sebagai kepala keluarga sebanyak 783 orang.

a. Lulusan pendidikan umum :

\begin{tabular}{|c|c|c|c|c|c|}
\hline No & $\begin{array}{c}\text { Pendidikan } \\
\text { Terakhir }\end{array}$ & $\begin{array}{l}\text { Laki- } \\
\text { Laki }\end{array}$ & Perempuan & Jumlah & $\begin{array}{c}\text { Persentase } \\
\%\end{array}$ \\
\hline 1. & TK & 102 & 101 & 203 & 9.95 \\
\hline 2. & SD & 177 & 248 & 425 & 20.84 \\
\hline 3. & SLTP & 113 & 106 & 219 & 10.74 \\
\hline 4. & SLTA & 489 & 415 & 904 & 44.33 \\
\hline 5. & Akademi / D1-D3 & 11 & 66 & 77 & 3.77 \\
\hline 6. & Sarjana $(\mathrm{S} 1-\mathrm{S} 2)$ & 99 & 112 & 211 & 10.34 \\
\hline & Total & 991 & 1048 & 2039 & 100 \\
\hline
\end{tabular}

Sumber : Monografi kelurahan Tomalou

Dari data di atas dapat dijelaskan bahwa jumlah penduduk Kelurahan Tomalou yang mengenyam bangku pendidikan sebanyak 2039 orang dengan klasifikasi berdasarkan jenis kelamin laki-laki sebanyak 991 orang dan perempuan sebanyak 1048 orang. Dengan demikian dapat di asumsikan berdasarkan barometer data penyebaran berdasarkan pendidikan Masyarakat Kelurahan Tomalou memiliki kecenderungan berpikir progresif untuk peningkatan taraf kesejahteraannya melalui pemanfaatan potensi yang di miliki.

b. Mata Pencaharian 


\begin{tabular}{llcccc}
\hline No & $\begin{array}{l}\text { Jenis } \\
\text { Pekerjaan }\end{array}$ & Laki-laki & Perempuan & Jumlah & $\begin{array}{c}\text { Persentase } \\
\text { \% }\end{array}$ \\
\hline 1. & Nelayan & 340 & 41 & 381 & 89.64 \\
2. & TNI & 1 & - & 1 & 0.2 \\
3. & Polri & 11 & - & 11 & 2.58 \\
4. & Wiraswasta/ & 3 & 29 & 32 & 7.52 \\
& Pedagang & & & & \\
\hline \multicolumn{7}{r}{ Total } & 355 & 70 & 425 & 100 \\
\hline
\end{tabular}

Sumber : Monografi Kelurahan Tomalou

Berdasarkan data telly pada monografi Kelurahan Tomalou dapat di kelompokkan berdasarkan jenis kelamin, dengan jumlah nelayan laki-laki sebanyak 340 orang dan perempuan sebanyak 41 orang dengan presentase $89.64 \%$ bekerja sebagai Nelayan. Dengan demikian dapat di jelaskan bahwa sebahagian besar profesi masyarakat di Kelurahan Tomalou sebagai nelayan untuk mencukupi kebutuhan sehari-hari maupun sebagai upaya peningkatan taraf kesejahteraannya. 


\section{HASIL DAN PEMBAHASAN}

\subsection{Hasil}

Dari penelitian yang di lakukan terhadap para nelayan di Kelurahan Tomalou Kecamatan Tidore Selatan Kota Tidore Kepulauan, maka biaya dapat di klasifikasikan dalam 2 (dua) macam yaitu Biaya Investasi ( Pembelian Kapal Viber, Huhate, Jaring ) Biaya Produksi yang terdiri dari biaya tetap ( Perawtan kapal, penyusutan kapal, penyusutan alat tangkap ) sedangkan biaya variable adalah biaya operasional.

Untuk mengetahui kelayakan usaha armada motor ikan di Kelurahan Tomalou maka digunakan analisis kelayakan usaha sebagaimana di kemukakan oleh (Kadariah et al, 1978) Analisis biaya manfaat mencakup perhitungan biaya investasi, biaya eksploitasi, penerimaan, analisis kelayakan dengan menggunakan net present value (NPV), net benefit cost ratio (Net B/C) yang dijelaskan.

\subsubsection{Analisis Penerimaan dan Pendapatan}

Didalam suatu usaha biaya dan pendapatan perlu diketahui sehingga dapat mengukur tingkat keuntungan yang diperoleh. Untuk mengukur keuntungan dari suatu usaha digunakan formula yang dikemukakan oleh Soetrisno (1981).

$$
\pi=\mathrm{TR}-\mathrm{TC} .
$$

Dimana : 


$$
\begin{aligned}
& \pi=\text { Keuntungan absolut } \\
& \mathrm{TR}=\text { Total pendapatan } \\
& \mathrm{TC}=\text { Total Biaya }
\end{aligned}
$$

a. Biaya Produksi

Biaya adalah sejumlah korbanan atau input yang di keluarkan untuk mendapatkan/menghasilkan masukan berupa output. Dengan demikian juga yang di lakukan oleh para pengusaha armada motor ikan di Kelurahan Tomalou, untuk mengetahui besaran biaya yang di keluarkan oleh para responden maka dapat dilihat pada Tabel 1 di bawah ini : Tabel 1. Análisis biaya usaha armada motor ikan di Kelurahan Tomalou

\begin{tabular}{|c|l|r|r|}
\hline No & \multicolumn{1}{|c|}{ Nama Responden } & Biaya Investasi & \multicolumn{1}{|c|}{ Biaya Produksi } \\
\hline 1 & Hi. Abdullah & $142.680 .000,-$ & $100.960 .000,-$ \\
3 & Hi. Saleh & $77.620 .000,-$ & $81.892 .000,-$ \\
4 & Hi. Hasan & $97.680 .000,-$ & $293.759 .000,-$ \\
5 & Hi. Rasyid Abdullah & $142.680 .000,-$ & $330.009 .000,-$ \\
6 & Usman Salama & $82.680 .000,-$ & $227.009 .000,-$ \\
7 & M Jufri Hi. Rajak & $142.680 .000,-$ & $247.647 .200,-$ \\
8 & Ahmad Hasan & $107.680 .000,-$ & $244.420 .400,-$ \\
9 & Yasin Salasa & $111.620 .000,-$ & $221.690 .600,-$ \\
10 & Hi. Ishak Hi. Din & $142.620 .000,-$ & $266.989 .800,-$ \\
11 & Hi. Jen M Nur & $107.635 .000,-$ & $220.979 .350,-$ \\
12 & Baswan Hi. Wahab & $112.620 .000,-$ & $198.485 .800,-$ \\
13 & Muksin Salim & $97.620 .000,-$ & $221.987 .000,-$ \\
\hline
\end{tabular}

Sumber : Data Primer setelah di olah 2010

Dari data tabel di atas maka dapat di jelaskan bahwa biaya yang di butuhkan dalam setiap usaha nelayan viber di Kelurahan Tomalou dengan nilai nominal biaya investasi sebesar $\geq$ Rp. 100.000.000,-/ Tahun dan di butuhkan biaya Produksi yang merupakan 
penjumlahan antara biaya variable di tambahkan dengan biaya tetap dengan besaran $\geq$ 200.000.000,-/ Tahun.

b. Analisis Keuntungan

Keuntungan merupakan suatu dari hasil penjualan akan barang atau jasa kepada konsumen. Dan dalam usaha sektor perikanan yang di lakukan oleh nelayan di Kelurahan Tomalou diperlukan suatu analisis usaha untuk mengetahui usaha tersebut menguntungkan ( layak untuk di kembangkan ) ataukah tidak, pendapatan usaha nelayan viber di Kelurahan Tomalou dapat analisis dengan membandingkan total penerimaan di kurangi total biaya.

1. Analisis Penerimaan

Dalam menganalisis penerimaan atau pendapatan usaha nelayan viber di Kelurahan Tomalou dapat di lihat pada tabel 2 di bawah ini :

Tabel 2. Penerimaan Responden usaha armada motor ikan

\begin{tabular}{|l|l|c|}
\hline No & \multicolumn{1}{|c|}{ Nama Responden } & Penerimaan (Rp)/Tahun \\
\hline 1 & Hi. Abdullah & $280.000 .000,-$ \\
3 & Hi. Saleh & $140.000,000,-$ \\
4 & Hi. Hasan & $288.000 .000,-$ \\
5 & Hi. Rasyid Abdullah & $880.000 .000,-$ \\
6 & Usman Salama & $96.000 .000,-$ \\
7 & M Jufri Hi. Rajak & $204.000 .000,-$ \\
8 & Ahmad Hasan & $160.000 .000,-$ \\
9 & Yasin Salasa & $136.800 .000,-$ \\
10 & Hi. Ishak Hi. Din & $216.000 .000,-$ \\
11 & Hi. Jen M Nur & $126.000 .000,-$ \\
\hline
\end{tabular}




\begin{tabular}{|l|l|c|}
\hline 12 & Baswan Hi. Wahab & $194.400 .000,-$ \\
13 & Muksin Salim & $152.200 .000,-$ \\
\hline
\end{tabular}

Sumber : Data primer setelah di olah 2010

Berdasarkan data di atas dapat di jelaskan bahwa nilai pendapatan para nelayan viber sangat berfariasi dan sesuai dengan jumlah hasil tangkapan yang di pasarkan kepada konsumen selama satu tahun.

2. Analisis Pendapatan

Pendapatan yang di terima oleh nelayan di Kelurahan Tomalou dapat di lihat pada tabel 3 di bawah ini :

Tabel 3. Deskripsi Pendapatan nelayan di Kelurahan Tomalou / tahun

\begin{tabular}{|l|l|r|r|r|}
\hline No & \multicolumn{1}{|c|}{ Nama Responden } & \multicolumn{1}{|c|}{ Penerimaan } & \multicolumn{1}{|c|}{ Biaya } & \multicolumn{1}{|c|}{ Keuntungan } \\
\hline 1 & Hi. Abdullah & $280.000 .000,-$ & $243.640 .000,-$ & $36.360 .000,-$ \\
2 & Hi. Saleh & $140.000,000,-$ & $81.892 .077,-$ & $8.488 .000,-$ \\
3 & Hi. Hasan & $288.000 .000,-$ & $391.439 .000,-$ & $-103.439 .000,-$ \\
4 & Bakar Farah & $880.000 .000,-$ & $142.680 .000,-$ & $327.311 .000,-$ \\
5 & Hi. Rasyid Abdullah & $96.000 .000,-$ & $309.689 .000,-$ & $-213.689 .000,-$ \\
6 & Usman Salama & $204.000 .000,-$ & $390.327 .200,-$ & $-186.327 .200,-$ \\
7 & M Jufri Hi. Rajak & $160.000 .000,-$ & $352.100 .400,-$ & $-152.100 .400,-$ \\
8 & Ahmad Hasan & $136.800 .000,-$ & $333.310 .600,-$ & $-162.510 .600,-$ \\
9 & Yasin Salasa & $216.000 .000,-$ & $409.609 .000,-$ & $-193.609 .800,-$ \\
10 & Hi. Ishak Hi. Din & $126.000 .000,-$ & 328.614 .350 & $-202.614 .350,-$ \\
11 & Hi. Jen M Nur & $153.600 .000,-$ & $311.105 .800,-$ & $-71.105 .800,-$ \\
12 & Baswan Hi. Wahab & $194.400 .000,-$ & $221.987 .000,-$ & $-103.607 .000,-$ \\
13 & Muksin Salim & $152.200 .000,-$ & $332.053 .000,-$ & $-210.454 .000,-$ \\
\hline
\end{tabular}

Sumber ; Data primer setelah diolah 2010 
Berdasarkan data di atas dapat disimpulkan bahwa pendapatan nelayan di Kelurahan Tomalou sangat berfariasi dan dari total responden ada sebanyak 10 responden yang usahanya tidak layak untuk di kembangkang, namun sebanyak 3 orang pemilik perahu motor viber msaih layak untuk di kembangkan.

c. Analisis Kelayakan Usaha

Untuk mengukur layak tidaknya usaha yang di laksanakan oleh nelayan perahu motor viber di Kelurahan Tomalou maka akan di gunakan Rumus R/C rasio, yaitu dengan membandingkan tingkat penerimaan yang di peroleh dengan total biaya yang di keluarkan, maka revenue per cost diperoleh : dan dapat di lihat pada tabel 4 di bawah ini :

Tabel 4. Deskripsi R/C Ratio nelayan di Kelurahan Tomalou

\begin{tabular}{|l|l|r|r|c|}
\hline No & \multicolumn{1}{|c|}{ Nama Responden } & \multicolumn{1}{|c|}{ Biaya } & Penerimaan & R/C Ratio \\
\hline 1 & Hi. Abdullah & $243.640 .000,-$ & $280.000 .000,-$ & $1,1,-$ \\
3 & Hi. Saleh & $81.892 .077,-$ & $140.000,000,-$ & $1,7,-$ \\
4 & Hi. Hasan & $391.439 .000,-$ & $288.000 .000,-$ & $0,0,-$ \\
5 & Bakar Farah & $142.680 .000,-$ & $880.000 .000,-$ & $6,1,-$ \\
6 & Hi. Rasyid Abdullah & $309.689 .000,-$ & $96.000 .000,-$ & $0,3,-$ \\
7 & M Jufri Hi. Rajak & $352.100 .400,-$ & $160.000 .000,-$ & $0,4,-$ \\
8 & Ahmad Hasan & $333.310 .600,-$ & $136.800 .000,-$ & $0,4,-$ \\
9 & Yasin Salasa & $409.609 .000,-$ & $216.000 .000,-$ & $0,5,-$ \\
10 & Hi. Ishak Hi. Din & 328.614 .350 & $126.000 .000,-$ & $0,3,-$ \\
11 & Hi. Jen M Nur & $311.105 .800,-$ & $153.600 .000,-$ & $0,4,-$ \\
12 & Baswan Hi. Wahab & $221.987 .000,-$ & $194.400 .000,-$ & $0,8,-$ \\
13 & Muksin Salim & $332.053 .000,-$ & $152.200 .000,-$ & $0,4,-$ \\
& & & & $0,5,-$ \\
\hline
\end{tabular}

Sumber : Data primer setelah di olah 2010 
Berdasarkan data di atas dapat di jelaskan bahwa dari nilai $\mathrm{R} / \mathrm{C}$ rasio yang lebih besar dari 1,5 sesuai dengan pendapat Wijayah dan Abdullah (2003), bahwa setiap penambahan biaya Rp. 100,- akan memperoleh penerimaan Rp. 1,5 oleh karena itu usaha layak di kembangkan.

Dari penelitian ini dapat di jelaskan pula bahwa dari total jumlah responden yang berprofesi sebagai nelayan hanya 3 nelayan yang usahanya layak di kembangkan karena, memiliki R/C Ratio lebih besar dari 1.

Selain menggunakan R/C Ratio untuk mengetahui layak tidaknya usaha maka dapat pula di gunakan rumus Net Present Value (NPV) sebagaimana terdapat pada tabel di bawah ini :

Tabel 4. Deskripsi Net Present Value

\begin{tabular}{|c|l|c|c|}
\hline Tahun & \multicolumn{1}{|c|}{ Nama Responden } & $\begin{array}{c}\text { DF 5.5 \% } \\
\text { (Discont factor) }\end{array}$ & NPV \\
\hline 1 & Hi. Abdullah & 0.947 & 34.646 .454 .98 \\
2 & & 0.898 & 50.636 .778 .15 \\
3 & & 0.851 & 65.092 .219 .40 \\
\hline \multicolumn{2}{|c|}{ Jumlah } & 150.142 .680 .00 \\
\hline
\end{tabular}

Sumber : Data Primer setelah di olah 2010

Berdasarkan tabel di atas maka NPV dari usaha Hi.Abdulah adalah 150.142.680,-142.680.000,- $=7.450 .452,-$ maka dapat di simpulkan bahwa usaha neleyan perikanan layak di usahakan sebab nilai NPV lebih besar dari nilai investasi.

Tabel 5. Deskripsi Net Present Value

\begin{tabular}{|c|l|c|c|}
\hline Tahun & Nama Responden & $\begin{array}{c}\text { DF 5.5 \% } \\
\text { (Discount Factor) }\end{array}$ & NPV \\
\hline 1 & Hi. Saleh & 0.947 & 8.045 .497 .63 \\
2 & & 0.898 & 32.787 .731 .74 \\
3 & & 0.851 & 54.918 .861 .98 \\
\hline
\end{tabular}




\begin{tabular}{|c|c|}
\hline Jumlah & 95.747 .091 .35 \\
\hline
\end{tabular}

Sumber : Data primer setelah di olah 2010

Berdasarkan tabel di atas maka NPV dari usaha Hi.Abdulah adalah 95.747.091.35,-77.620.000,-,- = 18.127.091,- maka dapat di simpulkan bahwa usaha neleyan perikanan layak di usahakan sebab nilai NPV lebih besar dari nilai investasi.

Tabel 6. Deskripsi Net Present Value

\begin{tabular}{|c|l|c|c|}
\hline Tahun & Nama Responden & $\begin{array}{c}\text { DF 5.5 \% } \\
\text { (Discont Factor) }\end{array}$ & NPV \\
\hline 1 & Bakar Farah & 0.948 & $758.293 .838,-$ \\
2 & & 0.898 & $790.638 .125,-$ \\
3 & & 0.852 & $817.549 .117,-$ \\
\hline \multicolumn{2}{|c|}{ Jumlah } & $2.366 .481 .082,-$ \\
\hline
\end{tabular}

Sumber : Data primer setelah di olah 2010

Berdasarkan tabel di atas maka NPV dari usaha Hi.Abdulah adalah2.366.481.082,-142.680.000,-,- $=2.223 .801 .082,-$ maka dapat di simpulkan bahwa usaha neleyan perikanan layak di usahakan sebab nilai NPV lebih besar dari nilai investasi.

Dalam analisis keuntungan dapat menggunakan Internal Rate of Return (IRR) untuk mengetahui tingkat pengembalian bunga usaha, dapat di anggap sebagai tingkat keuntungan atas investasi dalam suatu usaha ( Kadariah et al, 1978).

Secara sederhana dapat juga menggunakan rumus Adi (2007) dalam Analisis Usaha Kecil dan Menengah. Maka, misalkan

$$
0=- \text { Rp. } 100+\frac{\mathrm{Rp} \cdot 40}{(1+\mathrm{IRR})^{1}} \text { sampai tahun ke }-\mathrm{n}
$$

Di sini perlu trial and eror ( coba - coba ) dalam menentukan suku bunga. 
Dari hasil penelitian ini maka IRR dari responden dapat di ketahui ( Lihat Lampiran 37-39 ) bahwa untuk usaha perikanan sebagai nelayan dengan suku bunga deposito sebesar $5,5 \%$ dan bila di bandingkan dengan investasi serta pendapatan per tahun oleh nelayan maka membutuhkan IRR sebesar $10-24 \%$ untuk pengembalin bunga Bank selama 3 tahun usaha.

Untuk mengetahui lamanya waktu yang di perlukan untuk mengembalikan investasi, maka dengan hasil penelitian pada nelayan tomalou maka dapat di ketahui lama pengembalian investasi sebagai berikut :

Tabel 7. Deskripsi Pay Back Period (PBP)

\begin{tabular}{|c|l|c|}
\hline No & Nama Responden & PBP (Pay Back Period) \\
\hline 1 & Hi. Abdullah & 2,6 Tahun \\
2 & Hi. Saleh & 2,5 Tahun \\
3 & Bakar Farah & 2,5 Tahun \\
\hline
\end{tabular}

Sumber : Data Primer setelah di olah 2010

Dari tabel di atas dapat di jelaskan bahwa untuk mengembalikan investasi maka di butuhkan waktu selama 2,5 tahun sampai dengan 2,6 tahun.

\section{d. Analisis Peralihan Profesi}

untuk menganalisis peralihan profesi dari nelayan ke profesi lain maka penulis menggunakan analisis persentase setelah menganalisis layak tidaknya usaha nelayan ikan di Kelurahan Tomalou. Dari data setelah di olah dapat di ketahui sebagai berikut:

Tabel 8. Deskripsi perralihan Profesi nelayan Kelurahan Tomalou

\begin{tabular}{|l|l|c|c|}
\hline No & Mata Pencaharian & Jumlah & Persentase \\
\hline 1 & Nelayan & 3 & 23 \\
\hline
\end{tabular}




\begin{tabular}{|l|l|c|c|}
\hline 2 & Wiraswasta & 9 & 69 \\
3 & Petani & 1 & 8 \\
\hline \multicolumn{2}{r|}{ Jumlah } & 13 & 100 \\
\hline
\end{tabular}

Sumber : Data Primer setelah di olah 2010

Dari data di atas dapat dijelaskan bahwa dari total responden yang memiliki usaha sebagai nelayan perahu motor viber di Kelurahan Tomaloundari total responden dan yang beralih profesi ke profesi lain sebagai wiraswasta sebanyak $69 \%$ dan sebagai petani sebanyak $8 \%$.

e. Analisis Kelayakan Usaha ( Rata-rata nelayan di Kelurahan Tomalou)

Untuk mengetahui rata-rata nelayan yang layak meneruskan atau tidaknya usaha maka di gunakan R/C Ratio rata-rata sebagai berikut :

Tabel 9. R/C Ratio rata-rata nelayan di Kelurahan Tomalou

\begin{tabular}{|l|c|}
\hline \multicolumn{1}{|c|}{ Uraian } & Jumlah (Rp) \\
\hline Total Biaya & $3.848 .447 .427,-$ \\
Total Penerimaan & $3.027 .000 .000,-$ \\
\hline
\end{tabular}

Sumber : Data Primer setelah di olah 2010

Dari tabel di atas dapat di jelaskan bahwa untuk mengetahui R/C Rationya maka Penerimaan Total di bagi dengan Total Biaya maka,

$$
\begin{aligned}
\mathrm{R} / \mathrm{C}= & \frac{3.027 .000 .000}{3.848 .447 .427} \\
& =0,78
\end{aligned}
$$

Dari perhitungan R/C Ratio di ketahui bahwa usaha nelayan di Kelurahan Tomalou tidak layak untuk di kembangkan sebab R/C Ratio lebih kecil dari 1. 


\subsection{Pembahasan}

\subsubsection{Biaya Produksi}

Kartasapoetra (1998) mengemukakan pendapat bahwa biaya produksi adalah semua pengeluaran yang harus di keluarkan produsen untuk memperoleh faktor-faktor produksi dan bahan-bahan penunjang lainnya yang akan di gunakan agar produk-produk tertentu yang telah di rencanakan dapat terwujud dengan baik.

Berdasarkan penjelasan di atas maka untuk melangsungkan setiap usaha maka di perlukan faktor-faktor produksi untuk menjaga kontinuetas dan kelancaran dalam setiap kegiatan usaha.

Berdasasrkan hasil penelitian pada nelayan viber di Kelurahan Tomalou maka dapat dilihat pada lampiran tabel 4 dan lampiran 1 sampai 36 deskripsi analisis biaya, bahwa untuk melakukan usaha armada motor ikan oleh nelayan Tomalou harus membutuhkan biaya sebesar Rp. 81.892.077,-- sampai Rp. 409.609.000,-

\subsubsection{Penerimaan (Revenue)}

Penerimaan adalah sejumlah pemasukan berupa hasil penjualan atas produk tertentu oleh produsen kepada konsumen dalam jumlah tertentu tergantung dari kualitas dan fluktuasi harga. Menurut Suyadi Prawirosentono, adalah bahwa total penghasilan (total revenue) perusahaan sama dengan total biaya yang di keluarkan. Dalam ilmu ekonomi mikro, dapat di kenal sebagai TR $=\mathrm{TC}$, atau total revenue sama dengan total cost .

Dari hasil penelitian terhadap para nelayan di Kelurahan Tomalou setelah di analisis berdasarkan penerimaannya maka para nelayan armada viber memeliki penerimaan setelah melakukan penjualan atas hasil tangkapan per tahun yang berkisar antara Rp. 96.000.000,samapai Rp. 880.000.000,-.

\subsubsection{Pendapatan}


Keuntungan merupakan selisih antara penerimaan setelah di kurangi dengan biaya yang di keluarkan oleh produsen. Ini juga oleh para nelayan di Kelurahan Tomalou melakukan kalkulasi untuk mendapatkan keuntungan yang sesuai dengan hasil penelitian ini maka keuntungan yang di peroleh berkisar Rp. 8.488.000,- sampai Rp. 327.311.000,-

Dalam soekartawi, (1995) bahwa pendapatan merupakan selisih antara penerimaan dan semua biaya-biaya yang di keluarkan. Berdasarkan penjelasan ini maka telah di ketahui berapa besar jumlah pendapatan yang di peroleh para nelayan, dapat di lihat pada lampiran 1 sampai 36.

\subsubsection{Kelayakan Usaha Nelayan}

Untuk mengetahui prospek pengembangan serta kelayakan usaha armada motor ikan di Kelurahan Tomalou, dapat dilakukan dengan menggunakan analisis kelayakan usaha. Di dalam menilai kelayakan usaha perlu dilakukan analisis biaya manfaat, analisis dimaksudkan agar pengusaha petani mendapat gambaran kelayakan usaha yang dilakukan. Dengan demikian para pengusaha (pembudidaya) dapat mengetahui untung rugi usaha yang dikembangkan dan kapan modal dapat kembali (Prianto, 2003).

Dari hasil penelitian yang dilakukan terhadap nelayan di Kelurahan Tomalou dengan jumlah sampel sebanyak 13 orang dan setelah data di olah secara statistik maka dapat di ketahui sebanyak 10 orang armada motor ikan yang tidak layak di usahakan dan sebanyak 3 responden memiliki usaha yang layak untuk di kembangkan, ( Lihat lampiran 1 sampai 40 ).

Dalam menilai layak tidaknya usaha armada motor ikan di Kelurahan Tomalou maka di gunakan beberapa metode untuk mengukur indikator kelayakan usaha yang diantaranya bahwa dalam peneliyian ini dapat di ketahui total biaya yang di keluarkan selama produksi berkisar Rp. 81.892.077,- sampai Rp. 243.640.000,- dan penerimaan yang di peroleh dari hasil tangkapan setelah di jual sebesar Rp. 140.000.000,- sampai dengan Rp. 880.000.000,- 
dengan nilai $\mathrm{R} / \mathrm{C}$ ratio 1,1 sampai 6,1 sehingga usaha di nyatakan layak. ( Lihat lampiran 1 sampai 36 dan tabel 4).

Net Persent Value (NPV) yang di peroleh adalah Rp. 7.450.452,- sampai Rp. 948.517.652,- dengan demikian usaha ini dinyatakan layak sebab NPV lebih besar dari investasi yang di keluarkan. Selain melihat NPV dapat juga di ketahui Internal Rate of Return (IRR) di sini perlu trial and eror (coba-coba) dalam menentukan suku bunga.

Dari hasil penelitian ini maka IRR dari responden dapat diketahui ( lihat Lampiran 37 sampai 39 ) bahwa untuk usaha perikanan sebagai nelayan dengan suku bunga deposito sebesar 5,5\% dan bila dibandingkan dengan investasi serta pendapatan pertahun oleh nelayan maka membutuhkan IRR sebesar 10 sampai 24 persen untuk pengembalian bunga Bank selama 3 tahun usaha. Sedangkan Pay back Period ( PBP ) atau berapa lama waktu yang dibutuhkan untuk mengembalikan investasi maka pada usaha nelayan armada motor ikan di Kelurahan Tomalou membutuhkan waktu 2,5 sampai 2,6 tahun ( lihat lampiran 40 sampai 42 ) . 


\section{KESIMPULAN DAN SARAN}

\subsection{Kesimpulan}

Berdasarkan penelitian dan uraian pembahasan di atas, maka dapat di tarik kesimpulan sebagai berikut :

1. Usaha nelayan perahu motor ikan viber yang layak di usahakan terdapat 3 perahu motor dan 10 responden dinyatakan tidak layak.

2. Indicator kelayakan usaha dapat di lihat dari perbandingan investasi dengan penerimaan serta lama waktu yang di butuhkan untuk mengembalikan investasi dan dalam penelitian ini maka nelayan perahu motor ikan di Kelurahan Tomalou membutuhkan waktu 2,5 sampai 2,6 tahun untuk pengembalian investasi dengan suku bunga 10 sampai $24 \%$.

3. Peralihan profesi dari nelayan ke profesi lain dengan persentase $69 \%$ mengalihkan profesi sebagai wiraswasta dan $8 \%$ sebagai Petani.

4. Potensi perikanan yang melimpah dan di tunjang dengan geografis yang strategis maka sangat potensial dilakukan pengembangan usaha di sektor perikanan dan juga tingkat konsumsi konsumen terhadap ikan yang tinggi.

\subsection{Saran}

Adapun saran yang perlu di sampaikan sebagai berikut : 
1. Adanya perhatian dari dinas terkait dalam upaya peningkatan usaha perahu motor ikan viber di Kelurahan Tomalou.

2. Pemerintah dalam memberikan stimulus harus menjalankan fungsi control serta pendampingan tentang manajemen usaha.

\section{DAFTAR PUSTAKA}

Adi Kwartono M. 2007. Analisis Usaha Kecil dan Menengah. Yogyakarta : CV. ANDI OFFSET.

Dahuri R. 2003a. Paradigma Baru Pembangunan Indonesia Berbasis Kelautan. Jakarta

Dahuri R. 2003b. Keanekaragaman Hayati Laut. Aset Pembangunan Berkelanjutan Indonesia Indonesia. Jakarta: PT. Gramedia Pustaka Utama.

[Ditjen] Direktorat Jenderal Perikanan. 1995. Promosi Peluang Usaha di Bidang Perikanan, Jakarta: Direktorat Jenderal perikanan, Departemen Pertanian.

[DKP] Departemen Kelautan dan Perikanan. 2001. Pedoman Umum Pengelolaan Pulaupulau Kecil yang Berkelanjutan dan Berbasis Masyarakat. Jakarta: Direktorat Jenderal Pesisir dan Pulau-Pulau Kecil.

[DKP] Departemen Kelautan dan Perikanan. 2002. Modul sosialisasi dan Orientasi Penataan Ruang Laut Laut Pesisir dan pulau-Pulau Kecil. Jakarta: Direktorat Tata Ruang Laut Pesisir dan Pulau-Pulau Kecil.

Gray C et al. 1993. Pengantar Evaluasi Proyek. Edisi Kedua. Jakarta: Gramedia Pustaka Utama.

Hernanto F, 1989. Ilmu Usaha Tani. PT. Penebar Suadaya Jakarta 
Kadariah L. Karlina, C. Gray. 1978. Pengantar Evaluasi Proyek. Lembaga Penyelidikan Ekonomi dan Masyarakat. Jakarta: Fakultas Ekonomi Universitas Indonesia

Mubyarto, 1987, Pengantar Ekonomi Pertanian.LP3ES, Jakarta

Prianto E. 2003. Seleksi dan Optimasi Lokasi Tambak Udang di Kawasan Pesisir Kota Dumai Propinsi Riau [tesis]. Bogor: Program Pascasarjana, Institut Pertanian Bogor. 129 hal.

Prianto E. 2003. Seleksi dan Optimasi Lokasi Tambak Udang di Kawasan Pesisir Kota Dumai Propinsi Riau [tesis]. Bogor: Program Pascasarjana, Institut Pertanian Bogor. 129 hal.

FX Sadikin. 2005. Meningkatkan Efisiensi, Produktifitas dan Profitabilitas, Yogyakarta

Seminar Hasil penilitian dan Pengembangan ekonomi Masyarakat Pesisir dan Pulau-Pulau Kecil- Kota Tidore Kepulauan, 2007 ).

Soekartawai 1986. Ilmu Usaha Tani, dan Penelitian untuk Pengembangan Petani ssKecil. Jakarta: Penerbit Universitas Indonesia Press. 